\title{
Sleep Quality in Pregnant Women Considering Maternal Age: A Cross-sectional Study
}

\section{Gebelik Yașına Göre Uyku Kalitesi Belirleyicileri: Kesitsel Bir Çalıșma}

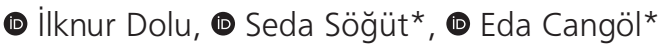 \\ Bartın University Faculty of Health Science, Department of Nursing, Bartın, Turkey \\ *Çanakkale Onsekiz Mart University Faculty of Health Science, Department of Midwifery, Çanakkale, Turkey
}

\begin{abstract}
Objective: This study aimed to determine the factors affecting the quality of sleep in pregnant women with respect to maternal age.

Materials and Methods: This cross-sectional study was conducted in the Gynecology and Obstetrics Outpatient Clinic of Bartın State Hospital. The research data were collected using questionnaires Whooley questions, Pittsburg sleep quality index, and the 12 -item shortform health survey.

Results: This study included 135 pregnant women, of whom 43 were $\geq 35$ years, 46 were $23-34$ years, and 46 were $\leq 29$ years old. The mean sleep quality score of the advanced maternal age group was 4.88 [standard deviation (SD), 2.27], which was lower than the maternal age group of 30-34 years (5.78; SD, 2.94) and $\leq 29$ years (5.02; SD, 3.38). Of the total participants, $52.6 \%$ were poor sleepers. Approximately $65 \%$ of the participants were Whooley-positive. The mean of the physical and mental component summary was 43.04 (SD, 6.04) and 44.05 (SD, 6.03), respectively, for each maternal age group. No significant differences were found among the maternal age groups in terms of sleep quality, depression, and quality of life.

Conclusion: The study results revealed similar characteristics among pregnant women of advanced and young maternal age concerning quality of life, sleep quality, and maternal depression.
\end{abstract}

Keywords: Sleep, sleep quality, quality of life, antenatal depression
Öz

Amaç: Bu çalışma, gebelik yaşına göre uyku kalitesini etkileyen faktörleri belirlemeyi amaçlamaktadır.

Gereç ve Yöntem: Bu kesitsel çalışma, Bartın Devlet Hastanesi'nde Kadın Hastalıkları ve Doğum Polikliniği'nde yapılmıştır. Araştırma verileri anket formu, Pittsburg uyku kalitesi indeksi, Whooley soruları ve SF-12 yaşam kalitesi ölçeği kullanılarak toplanmıştır.

Bulgular: Bu çalışmaya toplam 135 gebe katılmıştır. Gebelerin 43’ü 35 yaş ve üzerinde, 46'sı 23-34 yaş aralığında ve $46^{\prime}$ sı 29 yaş ve altındaydı. İleri anne yaş grubunun uyku kalitesi toplam puanı 4,88 [standart sapma (SS), 2,27], 30-34 yaş grubunun 5,78 (SS, 2,94) ve $\leq 29$ yaş grubunun $5,02(S S, 3,38)$ olarak hesaplandı. Katılımcıların yarısı $(\% 52,6)$ kötü uyku kalitesine sahipti. Katılımcıların yaklaşık \%65'inde Whooley pozitifti. Katılımcıların tamamı için fiziksel bileşen özetinin ortalaması 43,04 (SS, $6,04)$ ve mental bileşen özeti 44.05 (SS, 6,03) idi. Anne yaş grupları arasında uyku kalitesi, depresyon ve yaşam kalitesi açısından anlamlı fark bulunmadı.

Sonuç: Çalışma sonunda ileri yaş gebelerin, daha genç olanlar ile benzer şekilde düşük uyku kalitesi, depresyon ve yaşam kalitesine sahip olduğu bulundu.

Anahtar Kelimeler: Uyku, uyku kalitesi, yaşam kalitesi, gebelikte depresyon

\section{Introduction}

In recent years, with the increasing tendency to have childbearing in advanced ages worldwide, pregnancy rates of 35 years and older have also increased. Although definition of advanced maternal age (AMA) is globally not assertive, this term generally define as "childbearing in a woman over 35 years of age" (1). Many factors such as effective contraception methods, the increase in assisted reproductive technology, the insufficient financing status of young parents for child care, higher education level of women, and alongside the increase rate of employment of them in high positions contribute this growing tendency rate of childbearing at advanced ages (2). AMA is especially more common in high-income countries. The rate of first births to women aged 35 and older is $9.1 \%$ in 2014 with an increase of $23 \%$ in the last 14 years in the United States (3). In England and Wales, the average age of mothers giving birth for the first time was 28.8 years in 2017 (4). In Turkey, median maternal age at first delivery has risen from 20.8 years in 1993 to 23.3 years in 2018 (5). Additionally, The national data shows that $16 \%$ of deliveries in Turkey in 2018 were among women 35 years and older and this percentage 
was almost $11 \%$ at the beginning of 2000 s (6). These evidences show that there is a growing trend in being delayed moderhood among women in Turkey.

Most studies focusing on pregnant women with AMA are generally inquiry obstetrical outcomes $(7,8)$ and maternal comorbidities. However, scientific publications on sleep quality of pregnant women in older age are rare. Some studies assert that age is one of the determinants for sleep quality $(9,10)$, but there is not enough evidence to support an increased prevalence of poor sleep quality among AMA compared to other maternal ages.

Health-related quality of life (HRQoL) is affected during the pregnancy (11) and is shown a decrease along with the poor sleep quality (12). The sleep quality of women is one of the strong factors to predict HRQoL in pregnancy and adequate sleep is important for the optimal HRQoL of pregnant women (13). Additionally, the association between maternal age and HRQoL is a controversial issue (11) and there is a lack of scientific knowledge related to the HRQoL of pregnant women aged 35 years old and over, and its associations. The screening of HRQoL among pregnancy and its association e.g., sleep quality and depression is necessary $(1,11)$ to improve the future wellbeing of pregnant women and obstetric outcomes such as postnatal depression, preterm delivery, increased incidence of low-birth-weight infants.

The poor sleep quality and low HRQoL score are closely related to antenatal depression (13). Although the majority of women do not report complaints regarding depression (11), the prevalence of depression among pregnant women is rather prevalent worldwide in particular low-income countries (14). In Turkey, studies show that the prevalence rate of depression in pregnancy is almost $30 \%$ for all maternal (15). Although maternal age considers a risk factor to increase antenatal depression, developing depression among women in AMA is rarely investigated (14).

\section{Study Aims}

The aim of the present study was therefore to define factors affeting sleep quality in pregnant women considering maternal age.

Research questions are as follow:

- What are the main predictors of sleep quality in pregnant women considering maternal age?

- Are there relationship between maternal depression, quality of sleep and quality of life in pregnant women considering maternal age?

\section{Materials and Methods}

\section{Study design and setting}

In this cross-sectional study, we recruited pregnant women who visited the Gynecology and Obstetrics Outpatient Clinic of The Bartın State Hospital for a routine health check between December 2019-March 2020. The inclusion criteria were the following: (a) Aged $\geq 18$ years; (b) no severe maternal complications, (c) no serious health problems e.g., psychosis, major depression, cancer; (d) a singleton pregnancy.

\section{Participants and data collection}

Simple random sampling method was used in this study. The sample size was calculated using G-Power 3.1.9.7 based on the results of the previous studies (9), the effect size of quality of sleep in pregnant women aged $\geq 35,30-34$, and $\leq 29$ years old were hypothesized 0.6. A power analysis revealed that a sample size of 37 each group when the effect size was $0.6, \alpha$ (twosided) was 0.05 , and power was 0.8 . Accounting for potential withdrawal and missing data, 43 participants were selected. In total, 135 pregnant women participated in the study, of whom 43 were $\geq 35$ years of age, 46 were $30-34$ years of age, and 46 were $\leq 29$ years of age (16).

Data were collected using a paper-based survey including a questionnaire, the Whooley questions, item short form health survey-12 (SF-12), and Pittsburg sleep quality index (PSQI). The questionnaire designed based on the literature review and comprised of socio-demographic information and pregnancy history of participants. The socio-demographic information included age, pre-pregnancy weight, height, education level, and perceived income level. Body mass index (BMI) of participants was calculated by using pre-pregnancy weight (kilogram) and height (meter) (17). The obstetrical history consisted of gravida, parity, previous birth mode, miscarriage, presence of chronic diseases, live birth, and bad habits.

The sleep quality of participants was measured by the PSQI. This self-report scale is used to assess individuals' sleep quality over a one month time interval. The scale was validated with a Cronbach's alpha score of 0.80 by Ağargün et al. (18) in the Turkish context. PSQI compose seven components with 19 questions weighted on a scale of 0-3 that are used to calculate global score. A global score of $>5$ indicates that the individual's sleep quality is poor. Cronbach's alpha score was estimated as 0.74 in this study.

The Whooley questions was used for evaluation of perinatal depression (19). These questions comprise of three questions for defining aid and the help of perinatal depression. Pregnant women who answer one of the first two questions as "yes", those have to answer the third question as "yes, but not today or no". Participants responding either first two questions as "yes" were categorized as "Whooley positive", on the other hand those responding either first two questions as "no" were categorized as "Whooley negative". It is recommended that practitioners should be trained on how to be asked the Whooley questions (20). In the present study, the first author who have a Ph. D. degree asked the questions to pregnant women (21). Health-related quality of pregnant women was assessed by SF-12. This questionnaire was created by obtaining 12 items from every eight dimensions of the item short-form health survey-36 (SF-36) which was validated with a Cronbach's alpha score range between 0.73 and 0.76 by PInar (22) in the Turkish context. This survey contains eight components to evaluate the quality of life of individuals who are healthy or sick. SF-12 is a valid and practical alternative of SF-36. As for calculating SF-12 score, Ware et al.'s (21) scoring method was used to perform physical and mental standardization for each question. Then, physical standardization values and mental standardization 
values were summed separately for each item. Finally, physical component summary (PCS) score and mental component summary (MCS) score were calculated by adding 56,57706 and 60,75781 respectively. The scores of PCS and MCS are calculated as values ranging from 0 to100. The higher scores shows higher quality of life.

\section{Statistical Analysis}

Demographic data was reported using descriptive analyses. Pearson's chi-squared tests or Fisher's Exact tests in case of the smallest theoretical frequency $<5$ were used to compare categorical variables. The normality of the research data were tested using Skewness and Kurtosis values. Analysis of variance (ANOVA) was performed to compare maternal age groups and continuous variables and Pearson correlation was performed to test correlation between continuous variables. Statistical Package for the Social Sciences (SPSS) for Windows version 25.0 was performed to the data analysis. $\mathrm{P}<0.05$ was accepted for the significance level.

\section{Ethics}

The Ethics Committee of the Çanakkale Onsekiz Mart University (decree code: 2019/18) approved the study protocol. We informed pregnant women about the purpose of the study. Obtaining the informed consent to attend the study was guaranteed. The confidentiality of the data was assured by de-identifing of the questionnaires.

\section{Results}

Of the 135 responders recruited, 43 were 35 years old or over (mean age, $37.61 \pm 2.87$ years; range 35 and 46 years), 46 were between 30 and 34 (mean age, $31.85 \pm 1.69$ years; range 30 and 34 years) and 46 were 29 or younger (mean age, 24.09 \pm 3.28 years; range 18 and 29 years). Characteristics of participants $(\geq 35)$ and other maternal ages are illustrated in Table 1. Over half of the participants (67.4\%) were predominantly with normal pre-pregnant BMI, and almost half of them (44.4\%) were university educated. The majority pregnant women $(78.5 \%)$ perceived their income level as middle or low. Most pregnancy (88.1\%) was a planned pregnancy and $62.2 \%$ of them were in the third trimester. The rate of gravida and parity were higher (58.7\% and $32.6 \%$, respectively) in AMA group $(55.8 \%$ and $32.6 \%$ respectively) than other maternal age groups $(23.9 \%$ in 30 -34 maternal age and $13.0 \%$ in $\leq 29$ maternal age; $p=0.00$ for gravida and $15.2 \%$ in $30-34$ maternal age and $13.1 \%$ in $\leq 29$ maternal age; $p=0.01$ for parity). The rate of the miscarriage was greater (48.8\%) in the participants aged 35 years old or over than other groups $(26.1 \%$ in the maternal age between 30 and 34 , and $13.0 \%$ in the maternal age $\leq 29 ; p=0.00$ ). Participants with AMA (30.2\%) had more chronic diseases that other maternal age groups (15.2\% in 30-34 maternal age and $8.7 \%$ in $\leq 29$ maternal age; $p=0.03$ ). Most previous birth mode (61.2\%) was vaginal, majority previous birth (93.1\%) was alive, and participants did not predominantly use tobacco or alcohol. There were significant differences among maternal age groups according to gravida, parity, miscarriage, and chronic diseases among included characteristics.
Quality of life, depression, and sleep quality of participants according to the age groups are shown in Table 2. The PSQI global score of AMA group was 4.88 [standard deviation (SD) 2.27] compared to maternal age group 30-34 with 5.78 (SD 2.94) and maternal age group $\leq 29$ with 5.02 (SD 3.38). $52.6 \%$ of the total participants were poor sleepers. Pregnant women mostly had very good subjective sleep quality (92.6\%). Although most participants (73.3\%) had $\geq 16$ minutes of sleep latency, $65.9 \%$ of pregnant women had $>7$ hours sleep duration and $63.7 \%$ of them had $\geq 85 \%$ sleep efficiency. In the range from 1 to 9 sleep disturbance was $67.4 \%$ and more than half of the participants had 1 to 2 daytime dysfunctions (57.0\%). The majority pregnant women did not take any sleeping medication (69.6\%). Approximately $65 \%$ of pregnant women were Whooley positive. The mean of the PCS was 43.04 (SD 6.04) and the MCS was 44.05 (SD 6.03) for each maternal age group. We did not find any significant differences among maternal age groups in terms of quality of life, sleep quality, and depression.

Correlations beween quality of life, depression, quality of sleep, and age are shown in Table 3. The mean global PSQI score was 5.24 ( $\mathrm{SD}= \pm 2.92$, range 0 to 15$)$, $\mathrm{PCS}$ was 43.04 ( $\mathrm{SD}=$ \pm 6.03 , range 28.10 to 58.08 ), MCS was 44.04 ( $S D= \pm 6.04$, range 29.97 to 61.18$)$, and age was $31.03(S D= \pm 6.15$, range 18 to 46). PSQI had moderate correlation with PCS [ $r=-0.330$, $95 \%$ confidence interval $(\mathrm{Cl})$ raging -0.24 to 0.08$]$. PCS had moderate correlation with PSQI $(r=-0.330,95 \% \mathrm{CI}$ raging -0.24 to 0.08 ) and had a weak correlation with MCS ( $r=-0.170$, $95 \% \mathrm{Cl}$ raging -0.34 to -0.00 ). Additionally, there were a weak correlation between age and depression.

The logistic regression were presented in Table 4. Factors included in this study explained $22 \%$ of variance in the poor sleep quality. PCS was the main predictor of poor sleep quality (odds ratio $=0.90,95 \% \mathrm{Cl}: 0.84-0.97, \mathrm{p}=0.006$ ).

\section{Discussion}

The present study shows that the main predictor of poor sleep quality was PCS of quality of life. Additionally, this study reveals that sleep quality, maternal depression, and quality of life in pregnant women with AMA were similar to those younger ages. A previous study including nullipara women reported that poor quality of sleep, poor physical health, and maternal depression were quire prevalent among pregnant women with AMA and very AMA compared to those with younger maternal ages (23). However, a study conducting in Vietnam reported that multipara women were poor sleepers compared to nullipara women regardless of maternal age differences (10). Previous studies reported that the rate of poor sleep quality among pregnant women was a range from $43 \%$ to $87 \%(9,10,24$ 26). Our present findings support previous results by showing $52.6 \%$ of poor sleep quality in the total sample.

A previous meta-analysis study reported that quality of sleep decreases as gestational age increase according to a comparison between the youngest sample (mean age, 23.8 years of age; standart deviation 4.1) and the oldest (mean age, 33.5 years of age; standart deviation 4.1) (24). Additionally, another study 


\begin{tabular}{|c|c|c|c|c|c|}
\hline Characteristics & $\begin{array}{l}\text { Maternal age } \geq 35 \\
\mathrm{n}(\%) \\
\mathrm{n}=\mathbf{4 3}\end{array}$ & $\begin{array}{l}\text { Maternal age } 30-34 \\
n(\%) \\
n=46\end{array}$ & $\begin{array}{l}\text { Maternal age } \leq \mathbf{2 9} \\
\mathrm{n}(\%) \\
\mathrm{n}=\mathbf{4 6}\end{array}$ & $x^{2}$ & $p$ \\
\hline \multicolumn{6}{|l|}{$\begin{array}{l}\text { Pre-pregnancy } \\
\mathrm{BMI}\left(\mathrm{kg} / \mathrm{m}^{2}\right)\end{array}$} \\
\hline Normal weight & $27(62.8)$ & $28(60.9)$ & $36(78.3)$ & \multirow{2}{*}{3.779} & \multirow{2}{*}{0.15} \\
\hline Overweight-obese & $16(37.2)$ & $18(39.1)$ & $10(21.7)$ & & \\
\hline \multicolumn{6}{|l|}{ Education level } \\
\hline Elementary school & $9(20.9)$ & $8(17.4)$ & $12(26.1)$ & \multirow{3}{*}{3.198} & \multirow{3}{*}{0.53} \\
\hline High school & $17(14.7)$ & $13(15.7)$ & $16(15.7)$ & & \\
\hline University & $17(39.5)$ & $25(28.3)$ & $18(34.8)$ & & \\
\hline \multicolumn{6}{|l|}{ Perceived income level } \\
\hline High & $11(25.6)$ & $7(15.2)$ & $11(23.9)$ & \multirow{2}{*}{1.660} & \multirow{2}{*}{0.44} \\
\hline Middle-low & $32(74.4)$ & $39(84.8)$ & $35(76.1)$ & & \\
\hline \multicolumn{6}{|l|}{ Planned pregnancy } \\
\hline Yes & $39(90.7)$ & $42(91.3)$ & $38(82.6)$ & \multirow{2}{*}{2.057} & \multirow[b]{2}{*}{0.41} \\
\hline No & $4(9.3)$ & $4(8.7)$ & $8(17.4)$ & & \\
\hline \multicolumn{6}{|l|}{ Gestational age } \\
\hline $1^{\text {st }}$ trimester (weeks $0-13$ ) & $2(4.7)$ & $1(2.2)$ & $7(15.2)$ & \multirow{3}{*}{1.648} & \multirow{3}{*}{$0.21^{\mathrm{a}}$} \\
\hline $2^{\text {nd }}$ trimester (weeks $14-28$ ) & $13(30.2)$ & $16(34.8)$ & $12(26.1)$ & & \\
\hline $3^{\text {rd }}$ trimester $($ weeks $\geq 29)$ & $28(65.1)$ & $29(63.0)$ & $27(58.7)$ & & \\
\hline \multicolumn{6}{|l|}{ Gravida } \\
\hline 1 & $7(16.3)$ & $16(34.8)$ & $27(58.7)$ & \multirow{3}{*}{26.862} & \multirow{3}{*}{$0.00^{*}$} \\
\hline 2 & $12(27.9)$ & $19(41.3)$ & $13(28.3)$ & & \\
\hline$\geq 3$ & $24(55.8)$ & $11(23.9)$ & $6(13.0)$ & & \\
\hline \multicolumn{6}{|l|}{ Parity } \\
\hline 0 & $12(27.9)$ & $22(47.8)$ & $29(63.0)$ & \multirow{3}{*}{12.831} & \multirow{3}{*}{$0.01^{*}$} \\
\hline 1 & $17(39.5)$ & $17(37.0)$ & $11(23.9)$ & & \\
\hline$\geq 2$ & $14(32.6)$ & $7(15.2)$ & $6(13.1)$ & & \\
\hline \multicolumn{6}{|l|}{ Miscarriage } \\
\hline No & $22(51.2)$ & 34 (73.9) & $40(80.0)$ & \multirow{2}{*}{14.127} & \multirow{2}{*}{$0.00^{*}$} \\
\hline Yes & $21(48.8)$ & $12(26.1)$ & $6(13.0)$ & & \\
\hline \multicolumn{6}{|l|}{ Previous birth mode ${ }^{b}$} \\
\hline Vaginal & $15(48.4)$ & $16(66.7)$ & $9(52.9)$ & \multirow{2}{*}{1.892} & 030 \\
\hline Caesarean & $16(51.6)$ & $8(33.3)$ & $8(47.1)$ & & | \\
\hline Live birthc & & & & & \\
\hline No & $6(16.7)$ & $8(26.7)$ & $4(21.1)$ & O 001 & 01 \\
\hline Yes & $30(83.3)$ & $22(73.3)$ & $15(78.9)$ & 0.981 & 0.61 \\
\hline Chronic diseases & & & & & \\
\hline No & $30(69.8)$ & $39(84.8)$ & $42(91.3)$ & 7365 & $002 *$ \\
\hline Yes & $13(30.2)$ & $7(15.2)$ & $4(8.7)$ & J & 0.03 \\
\hline Bad habits & & & & & \\
\hline No & $33(76.7)$ & $39(84.8)$ & $35(76.1)$ & & \\
\hline $\begin{array}{l}\text { Tobacco } \\
\text { Alcohol }\end{array}$ & $\begin{array}{l}8(18.6) \\
1(2.3)\end{array}$ & $\begin{array}{l}7(15.6) \\
0(0.0)\end{array}$ & $\begin{array}{l}9(19.1) \\
2(4.3)\end{array}$ & 2.158 & $0.79^{\star}$ \\
\hline
\end{tabular}


Dolu et al.

Sleep Quality and Advanced Maternal Age

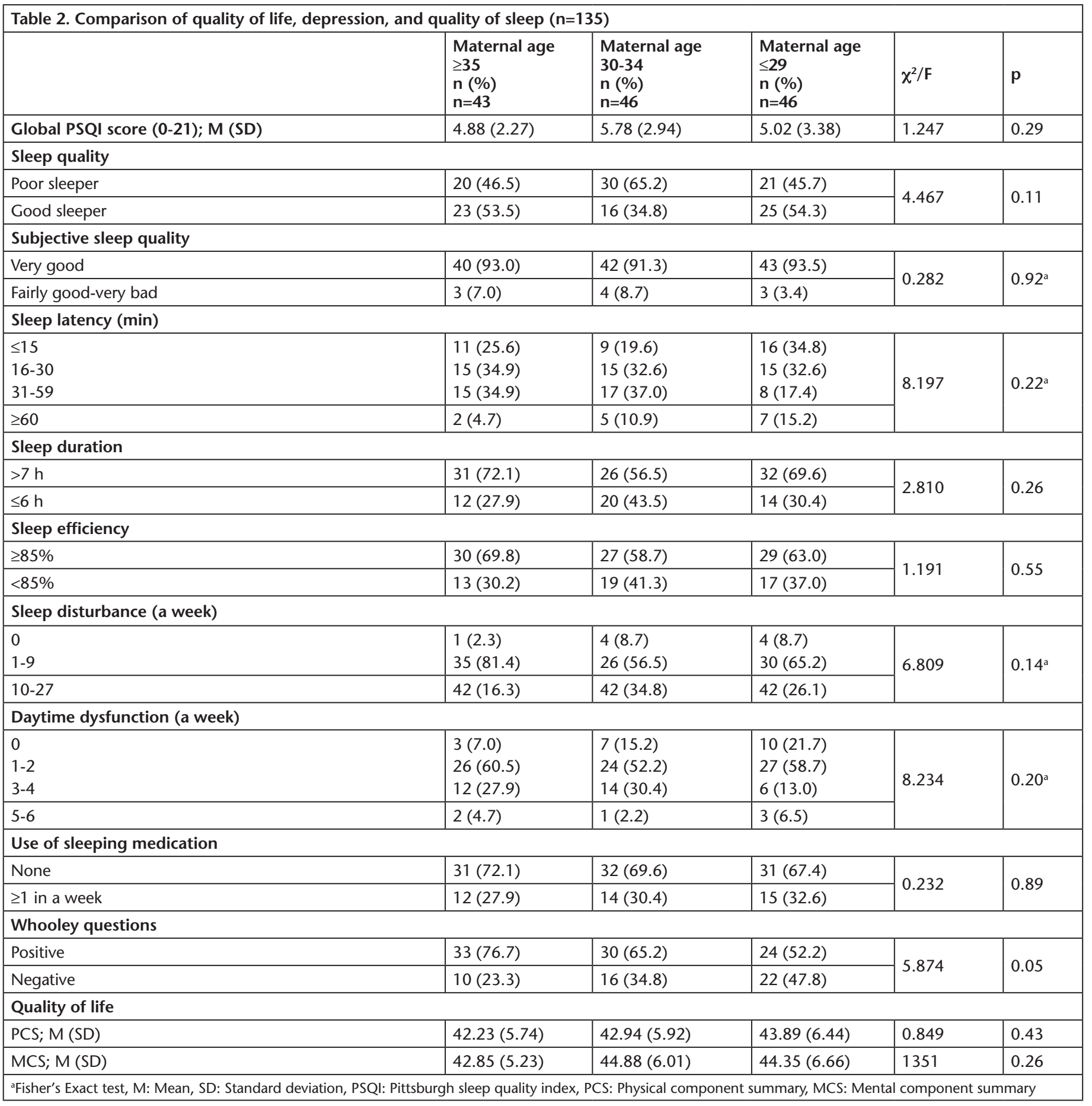

including a sample whose age was range from 19 to 40 years (mean age 28.5 years) demonstrated that older maternal age was significantly associated with poor sleep quality (9).

Our study findings does not define any significant correlation between age (mean age, 31.03 SD 6.15) and sleep quality. $53.5 \%$ of participants with AMA were good sleepers and there is no significant differences between maternal age groups. The good sleep quality may be related to characteristics of our study sample whose mean age was 37.61 years (SD 2.87). Although there were no significant differences between age groups, participants with AMA had lower global PSQI score which was below the cut-off score of 5 compared to those younger maternal ages. Additionally, the global PSQI score was 5.24 (SD 2.92) in each maternal age group. This result was not consistent with previous studies $(9,24,25)$ by determining lower PSQI score in each maternal age group.

As regards to dimensions of PSQI, this study did not find any significant differences between age groups in any dimension. A 
Dolu et al.

Sleep Quality and Advanced Maternal Age

\begin{tabular}{|c|c|c|c|c|c|c|}
\hline Variables & $M$ & SD & 1 & 2 & 3 & 4 \\
\hline 1. PSQI & 5.24 & 2.92 & & & & \\
\hline 2. PCS & 43.04 & 6.04 & $\begin{array}{l}-0.330^{* *} \\
(-0.24--0.08)\end{array}$ & & & \\
\hline 3. MCS & 44.04 & 6.03 & $\begin{array}{l}0.109 \\
(-0.03-0.14)\end{array}$ & $\begin{array}{l}-0.170^{*} \\
(-0.34--0.00)\end{array}$ & & \\
\hline 4. Age & 31.03 & 6.15 & $\begin{array}{l}-0.020 \\
(-0.4-0.32)\end{array}$ & $\begin{array}{l}-0.064 \\
(-0.24-0.11)\end{array}$ & $\begin{array}{l}-0.093 \\
(-0.27-0.08)\end{array}$ & \\
\hline 5. Depression & 1.36 & 0.48 & $\begin{array}{l}0.16 \\
(1.33-1.66)\end{array}$ & $\begin{array}{l}0.08 \\
(0.50-1.68)\end{array}$ & $\begin{array}{l}0.16 \\
(0.19-1.39)\end{array}$ & $\begin{array}{l}-0.17^{*} \\
(1.35-2.19)\end{array}$ \\
\hline
\end{tabular}

\begin{tabular}{|l|l|l|l|}
\hline Table 4. Factors associated with poor quality sleep \\
\hline & OR & $\% 95 \mathrm{Cl}$ & $\mathbf{p}$ \\
\hline Age & 1.02 & $0.95-1.10$ & 0.517 \\
\hline Educational level & 1.28 & $0.78-2.09$ & 0.322 \\
\hline Perceived income level & 1.06 & $0.49-2.29$ & 0.880 \\
\hline Gestational age & 1.04 & $0.99-1.09$ & 0.087 \\
\hline Gravida & 1.04 & $0.99-1.09$ & 0.087 \\
\hline Parity & 0.36 & $0.01-9.22$ & 0.534 \\
\hline Miscarriage & 0.18 & $0.01-7.60$ & 0.367 \\
\hline Live birth & 0.40 & $0.09-1.71$ & 0.214 \\
\hline Planned pregnancy & \multicolumn{5}{|l|}{} \\
\hline Yes & 1.00 & & \\
\hline No & 1.67 & $0.50-5.55$ & 0.406 \\
\hline Tobacco & 1.00 & & \\
\hline Yes & 1.35 & $0.47-3.86$ & 0.581 \\
\hline No & 1.00 & & \\
\hline Whooley & 0.81 & $0.36-1.85$ & 0.630 \\
\hline Positive & 0.90 & $0.84-0.97$ & 0.006 \\
\hline Negative & 1.01 & $0.95-1.08$ & 0.697 \\
\hline Physical component summary & \multicolumn{5}{|l}{} \\
\hline Mental component summary & \multicolumn{5}{|l|}{} \\
\hline OR: Odds ratio, Cl: Confidence interval & \multicolumn{5}{|l|}{} \\
\hline
\end{tabular}

used sleeping medications contrary to none in previous studies $(10,28)$.

According to a finish study, the prevalence of depression among pregnant women was 6.3\% (29). Previous studies reported a significant bidirectional association between sleep quality and prenatal depression $(9,24,25)$. In other words, poor sleep quality could be used as a predictor to define depression in pregnancy and poor sleep quality was aggravated by the presence of prenatal depression. Our present findings showed that $64.4 \%$ of pregnant women responded to the Whooley questions as positive and there was no significant difference in terms of AMA. Another distinction from previous studies, this study did not define any significant correlation between MCS of HRQoL and quality of sleep.

The association between quality of life, poor sleep quality $(11,30,31)$ and prenatal depression $(11,31)$ were reported in previous studies. Previous studies on quality of life in pregnancy indicated that PCS ranging from 45 to 50 and MCS was ranging from 47 to 57 (32) which were higher than our previous findings. The decreased quality of life may be relevant to the prevalence of tobacco or alcohol consumptions in our study sample (11). Our study findings supports an association between poor sleep quality and quality of life, but we did not find a difference between AMA and quality of life. These results were consistent with previous studies $(11,30)$. However, most previous studies have studied the quality of life and its associations among pregnant women, only a few studies reported quality of life in AMA $(11,30)$. According to current knowledge, it is unclear that there is an association between HRQoL and increased maternal age (30).

longer study showed that individuals grew older, they have their gender. Especially, 37 years of age is the breaking point for increasing sleep onset latency (27). Similarly, our study findings portrayed that pregnant women in each age group had longer sleep latency, and those with AMA did not have a different trend in sleep onset latency as well as other dimensions of PSQI. Our present findings regarding sleep onset latency, sleep duration, and high sleep efficiency has consisted of the results of the Huong et al.'s (10) study. However, the number of sleep disturbance and daytime dysfunction in a week was higher in our study sample than Huong et al.'s (10) study sample. Moreover, almost one-third of pregnant women in our study

\section{Study Limitations}

Several limitations should be considered in this study. First of all, our sample was selected from the gynecology and obstetrics outpatient clinic of a state hospital, and so the findings of previous study does not be generalized to the general population. In the second place, sleep quality was assessed by PSQI as subjectively only. In addition, we did not collect data on sleep hygiene practices, physical activity, a working status which those variables may confound our study findings. We advise a larger sample group taken into account 
a separation in which trimester pregnant women with AMA are and using an actigraph for evaluation of sleep quality of participants as objectively as well as self-report assessments for the future studies. Lastly, perinatal depression was only assessed by asking Whooley questions. Therefore, we recommed that furher studies should be conducted to compare Whooley questions and other depression scales in screening for perinatal depression in Turkey.

\section{Conclusion}

The present study illustrated that pregnant women with AMA had the similar characteristic to experience poor sleep quality, depression, low quality of life as younger maternal ages. Moreover, it was determined that the main predictor of poor sleep quality was PCS of quality of life. Taking into accond the increasing trend of AMA and their high risk of obstetric outcomes, healthcare professionals need to be conscious of the high risk of poor sleep quality, low quality of life, and depression which are closely related to poor obstetric outcomes. In particular, nurses and midwives as frontline healthcare providers can make an important contribution to improving pregnant women's quality of sleep, mental health, and quality of life through counseling, education programs, and pregnant schools.

With the role of the women in the modern working world, women conceive and give birth at advanced age compared to their previous generations. Increased knowledge about the quality of sleep in pregnancy and its bidirectional relationship with perinatal depression and quality of life is needed to develop strategies to prevent the negative effects of these factors on prenatal and fetal outcomes.

\section{Ethics}

Ethics Committee Approval: The Ethics Committee of the Çanakkale Onsekiz Mart University (decree code: 2019/18) approved the study protocol.

Informed Consent: Obtaining the informed consent to attend the study was guaranteed. The confidentiality of the data was assured by the-identifying of the questionnaires.

Peer-review: Externally peer-reviewed.

\section{Authorship Contributions}

Concept: I.D., S.S., E.C., Design: I.D., S.S., E.C., Data Collection or Processing: I.D., Analysis or Interpretation: I.D., Literature Search: I.D., S.S., E.C., Writing: I.D., S.S., E.C.

Conflict of Interest: No conflict of interest was declared by the authors.

Financial Disclosure: The authors declared that this study received no financial support.

\section{References}

1. Dillon CM, Ennen CS, Bailey KJ, Thagard AS. A comprehensive approach to care of women of advanced maternal age. Nurs Womens Health 2019;23:124-34.

2. Dietl A, Cupisti S, Beckmann MW, Schwab M, Zollner U. Pregnancy and obstetrical outcomes in women over 40 years of age. Geburtshilfe Frauenheilkd 2015;75:827-32.
3. Centers for Diseases Control and Prevention (CDC). Mean Age of Mothers is on the Rise: United States, 2000-2014. 2016. https:// www.cdc.gov/nchs/products/databriefs/db232.htm

4. Office for National Statistics. Birth characteristics in England and Wales: 2017. https://www.ons.gov.uk/ peoplepopulationandcommunity/birthsdeathsandmarriages/ livebirths/bulletins/birthcharacteristicsinenglandandwales/2017

5. Ministry of Health of Turkey. Turkish Demographic and Health Survey. 2019. http://www.hips.hacettepe.edu.tr/eng/tdhs2018/ TDHS_2018_main_report.pdf

6. Türkiye Istatistik Kurumu [Turkish Statistical Institute]. Hayati istatistikler [Life statistics]. 2020. http://www.tuik.gov.tr/PreTablo. do?alt_id=1060

7. Londero AP, Rossetti E, Pittini C, Cagnacci A, Driul L. Maternal age and the risk of adverse pregnancy outcomes: a retrospective cohort study. BMC Pregnancy Childbirth 2019;19:261.

8. Kahveci B, Melekoglu R, Evruke I, Cetin C. The effect of advanced maternal age on perinatal outcomes in nulliparous singleton pregnancies. BMC Pregnancy Childbirth 2018;18:343.

9. Yang Y, Mao J, Ye Z, Zeng X, Zhao H, Liu Y, Li J. Determinants of sleep quality among pregnant women in China: A cross-sectional survey. J Matern Fetal Neonatal Med 2018;31:2980-5.

10. Huong NTT, Thuy NTH, Yen LTH. Quality of Sleep among Pregnant Women. International Journal of Clinical Medicine 2019;10:16-25.

11. Lagadec N, Steinecker M, Kapassi A, Magnier AM, Chastang J, Robert $S$, Gaouaou N, Ibanez G. Factors influencing the quality of life of pregnant women: a systematic review. BMC Pregnancy Childbirth 2018;18:455.

12. Dağlar G, Bilgiç D, Aydın Özkan S. Factors affecting the quality of life among pregnant women during the third trimester of pregnancy. Cukurova Med J 2019;44:772-81.

13. Tsai SY, Lee PL, Lin JW, Lee CN. Cross-sectional and longitudinal associations between sleep and health-related quality of life in pregnant women: A prospective observational study. Int J Nurs Stud 2016;56:45-53.

14. Dadi AF, Miller ER, Bisetegn TA, Mwanri L. Global burden of antenatal depression and its association with adverse birth outcomes: an umbrella review. BMC Public Health 2020;20:173.

15. Çalıkoğlu EO, Bedir B, Aydın A, Yılmaz S. An investigation of the prevalence of depression and related factors in pregnant women living in the province of Erzurum. The European Research Journal 2018;4:381-9.

16. Laopaiboon M, Lumbiganon $\mathrm{P}$, Intarut $\mathrm{N}$, Mori R, Ganchimeg $T$, Vogel JP, Souza JP, Gülmezoglu AM; WHO Multicountry Survey on Maternal Newborn Health Research Network. Advanced maternal age and pregnancy outcomes: a multicountry assessment. BJOG 2014;121(Suppl 1):49-56.

17. Centers for Diseases Control and Prevention (CDC). Adult BMI Calculator. 2020. https://www.cdc.gov/healthyweight/assessing/ bmi/adult_bmi/english_bmi_calculator/bmi_calculator.html

18. Ağargün $M$, Kara $H$, Anlar Ö. The validity and reliability of the pittsburgh sleep quality index. Turk Psikiyatri Derg 1996;7:107-11.

19. Littlewood E, Ali S, Ansell P, Dyson L, Gascoyne S, Hewitt C, Keding A, Mann R, McMillan D, Morgan D, Swan K, Waterhouse B, Gilbody $S$; BaBY PaNDA study team. Identification of depression in women during pregnancy and the early postnatal period using the Whooley questions and the Edinburgh Postnatal depression scale: protocol for the born and bred in Yorkshire: Perinatal depression diagnostic accuracy (BaBY PaNDA) study. BMJ Open 2016;6:e011223.

20. Howard LM, Ryan EG, Trevillion K, Anderson F, Bick D, Bye A, Byford S, O'Connor S, Sands P, Demilew J, Milgrom J, Pickles A. Accuracy of the Whooley questions and the Edinburgh Postnatal Depression 
Dolu et al.

Sleep Quality and Advanced Maternal Age

Scale in identifying depression and other mental disorders in early pregnancy. Br J Psychiatry 2018;212:50-6.

21. Ware J Jr, Kosinski M, Keller SD. A 12-Item Short-Form Health Survey: construction of scales and preliminary tests of reliability and validity. Med Care 1996;34:220-33.

22. Pınar R. Reliability and construct validity of the SF-36 in Turkish cancer patients. Qual Life Res 2005;14:259-64.

23. Nilsen $A B$, Waldenström $U$, Hjelmstedt $A$, Rasmussen $S$, Schytt $E$. Characteristics of women who are pregnant with their first baby at an advanced age. Acta Obstet Gynecol Scand 2012;91:353-62.

24. Sedov ID, Cameron EE, Madigan S, Tomfohr-Madsen LM. Sleep quality during pregnancy: A meta-analysis. Sleep Med Rev 2018;38:168-76.

25. Yang Y, Li W, Ma TJ, Zhang L, Hall BJ, Ungvari GS, Xiang YT. Prevalence of Poor Sleep Quality in Perinatal and Postnatal Women: A Comprehensive Meta-Analysis of Observational Studies. Front Psychiatry 2020;11:161.

26. Lee PY, Liu LH, Ho C, Ang AJF, Huang HX, Teoh OH, Tan KH, Lee YS, Yap F, Gooley JJ, Chan SY, Cai S. Antenatal sleep quality associated with perinatal outcomes in women of advanced maternal age. Sleep Health 2020;6:60-4.

27. Tonetti L, Fabbri M, Natale V. Sex difference in sleep-time preference and sleep need: a cross-sectional survey among Italian preadolescents, adolescents, and adults. Chronobiol Int 2008;25:745-59.
28. Öztürk DM, Yılmaz A, Müsüroğlu S, Sevinç S, Akcan B. Son trimesterdeki gebelerin uyku kalitelerinin ve başetme yöntemlerinin belirlenmesi: Gebelikte son trimesterde uyku. Süleyman Demirel Üniversitesi Sağlık Bilimleri Dergisi 2019;10:212-6.

29. Toffol E, Lahti-Pulkkinen M, Lahti J, Lipsanen J, Heinonen K, Pesonen AK, Hämäläinen E, Kajantie E, Laivuori $H$, Villa PM, Räikkönen K. Maternal depressive symptoms during and after pregnancy are associated with poorer sleep quantity and quality and sleep disorders in 3.5-year-old offspring. Sleep Med 2019;56:201-10.

30. Kazemi F, Nahidi F, Kariman N. Assessment scales, associated factors and the quality of life score in pregnant women in Iran. Global Journal of Health Science 2016;8:127-39.

31. Zhang $H$, Zhang $Q$, Gao T, Kong $Y$, Qin Z, Hu Y, Cao R, Mei S. Relations between stress and quality of life among women in late pregnancy: The parallel mediating role of depressive symptoms and sleep quality. Psychiatry Investig 2019;16:363-9.

32. Hirasawa AC, Scarpa Romeo SC, Kurashima CH, Gélie FC, Takito MY. Health-related quality of life and leisure physical activity during pregnancy. Rev Bras Educ Fís Esporte 2017;31:629-38. 